\title{
LEGISLATIVE ACTIVITIES OF PUBLIC CHARITIES
}

\author{
Mortimer M. Caplin \\ RICHARD E. TIMBIE*
}

Congress in recent years has given increasing attention to the legislative activities of organizations exempt under section 501 (c)(3) of the Internal Revenue Code. ${ }^{1}$ In the 1969 Tax Reform Act, it took steps to prevent virtually all lobbying by private foundations. Public charities, ${ }^{2}$ on the other hand, continue to be governed by preexisting rules under section $50 \mathrm{l}(\mathrm{c})(3)$ which allow them limited room to participate in the legislative process.

These rules on legislative activities have long been criticized as unduly vague and restrictive, and since 1969 Congress has considered numerous proposals to enact clearer, more liberal standards. This article will examine the existing restrictions, evaluate the need for reform, and consider pending legislation aimed at providing greater certainty and broader latitude for public charities desiring to engage in legislative efforts.

\section{INTRODUCTION}

The definition of a charitable organization-both for income tax exemption under section $501(\mathrm{c})(3)$ and for deductible contributions under the income, estate, and gift tax laws3 -includes the following limitation: "no substantial part of the activities of [the organization] is carrying on propaganda, or otherwise attempting, to influence legislation . . . "This prohibition against substantial legislative activities first appeared in the Code in 1934. Since then the Treasury, federal courts, commentators, and, above all, the charitable organizations themselves have attempted, with only limited success, to answer the two questions it raises: (1) What sorts of activities constitute "propaganda" or "attempting to influence legislation"? (2) When does the amount of such activities become "substantial"?

\footnotetext{
* Caplin \& Drysdale, Washington, D.C.

The authors gratefully acknowledge the valuable assistance of Thomas A. Troyer and Frank M. Chapper in the preparation of this article.

1. INT. Rev. Code of 1954, \$501(c)(3). All statutory references unless otherwise indicated are to the Internal Revenue Code of 1954 , as amended.

2. Section $501(\mathrm{c})(3)$ exempts organizations organized and operated exclusively for certain purposes -including charitable, educational, and religious purposes. The term "public charity" as used herein refers $t o$ an organization which is exempt under section $50 \mathrm{l}(\mathrm{c})(3)$ and which meets the public support tests of section $509(\mathrm{a})(2)$ or (3).

3. INT. REV. CODE of 1954, $\$ \$ 170(\mathrm{c})(2)(\mathrm{D}), 2055(\mathrm{a})(2), 2106(\mathrm{a})(2)(\mathrm{A})(\mathrm{ii}), 2522(\mathrm{a})(2)$.
} 
Neither the Internal Revenue Code nor the Regulations contain adequate guidelines for answering these questions. The vagueness of the existing standards has created practical and administrative difficulties, and the effect of the restriction is to fence public charities out of the legislative process, a result which is contrary to sound public policy on a number of grounds.

Because numerous social and economic issues of special concern to charities are the subject of legislative proceedings, the existing restriction deters charities from using one of the most effective means of pursuing their goals. It also deprives legislators of the views of charities which are, in many cases, the only available spokesmen for interested groups that lack the funds or organization necessary for effective presentation.

While the Code effectively bars charities from participating in the legislative process on behalf of the public interest, it allows, and even encourages, lobbying on behalf of special economic and private interests. Businesses, trade associations, and a broad range of tax exempt organizations other than charities are permitted to lobby with tax exempt or tax deductible funds. This selective exclusion is contrary to the democratic concept that the views of all interested parties should be considered in formulating legislation; it is also inconsistent with first amendment guarantees of free speech and the right peaceably to petition government and the fifth amendment right to equal protection of law.

In recent years the legislative activities restriction has come under increasing criticism on administrative, public policy, and constitutional grounds. In 1968 the American Bar Association recommended liberalizing legislation. In the last five sessions of Congress, numerous bills have been introduced to effect such reform. Despite broad bipartisan support, reform legislation has repeatedly become mired in disputes which reflect both a lack of appreciation of the policy issues at stake and an exaggerated concern over possible abuses.

To help clarify the various issues, let us first review the scope and effects of present law and then analyze its impact on the organizations involved, the legislative process, and the public interest.

I

\section{The SCOPe ANd EfFEct of the Legislative ACTIVITY Restriction}

The Treasury and Internal Revenue Service have interpreted the statutory prohibition broadly, rejecting the construction that it limits only legislative activity which is not related to the organization's exempt purposes. However, they have established neither meaningful guidelines on the types of activity that are proscribed nor quantitative standards for assessing the substantiality of an organization's legislative efforts.

The absence of adequate definitions or standards places an undue administrative burden on all concerned. Revenue agents must undertake broad 
ranging investigations in each case and then make myriad factual and legal judgments. Furthermore, the vague substantiality test gives the Revenue Service undue discretion, which can lead to subjectivity and abuse.

Charities are faced with an untenable choice. In theory, they may participate in the legislative process so long as the activity is insubstantial. But only limited means are available for determining in advance what actually constitutes legislative activity or where the line will be drawn between insubstantial and substantial amounts. And because crossing the line will jeopardize a charity's exemption, most have largely avoided participation.

\section{A. Proscribed Activities}

\section{Relationship of Activity to Exempt Purpose Irreleviant}

To qualify for exemption under section 501(c)(3), an organization must be "organized and operated exclusively" for one of the charitable purposes specified in the Code. ${ }^{4}$ The Regulations provide that an organization is not so organized or operated unless it "serves a public rather than a private interest." In general, therefore, an exempt organization may engage in any form of activity which furthers its charitable purposes provided that activity is not carried on for the benefit of "private interests" including designated individuals, the creator or his family, or shareholders of the organization. ${ }^{6}$

Commentators who have reviewed the legislative history of the 1934 amendment which added the prohibition against legislative activity ${ }^{7}$ have concluded that Congress intended a more limited proscription than a literal reading of the statute would suggest. ${ }^{8}$ A persuasive case can be made that Congress (1) recognized that support of or opposition to legislation can be a legitimate means of furthering a charity's exempt program, ${ }^{,}$and (2) intended to bar only legislative activity conducted for the purpose of advancing the private interests of individuals associated with the exempt organization. ${ }^{10}$

\footnotetext{
4. See note 2 supra.

5. Treas. Reg. $\$ 1.501(\mathrm{c})(3)-1(\mathrm{~d})(1)(1967)$.

6. Treas. Reg. $\$ 1.501(\mathrm{c})(3)-1(\mathrm{~d})(1)(\mathrm{ii})(1967)$.

7. 48 Stat. $690,700,755,760$ (1934).

8. See, e.g., Borod, Lobbying for the Public Interest-Federal Tax Policy and Administration, 42 N.Y.U.L. REv, 1087, $1113-14$ (1967); Clark. The Limitation on Political Activities: A Discordant Note in the Law of Charities, 46 VA. L. Rev. 439, 447 (1960); Note, Political Activity and Tax Exempt Organizations Before and After the Tax Reform Act of 1969, 38 GEO. WASH. L. REV. $1114,1116-19$ (1970).

9. In the leading case of Slee v. Commissioner, 42 F.2d 184 (2d Cir. 1930), Judge Learned Hand affirmed the Commissioner's denial of a tax exemption to the American Birth Control League on the basis of the League's extensive political activities. However, Judge Hand stated that political activities are consistent with exempt status where they are "mediate" or "ancillary" to the primary exempt purposes of the organization. Id. at 185.

10. Senator Reed, one of the principal sponsors of the 1934 amendment, explained its language in the following terms:

There is no reason in the world why a contribution made to the National Economy League should be deductible as if it were a charitable contribution if it is a selfish one
} 
Such a construction has been suggested in two federal court decisions. ${ }^{11}$

Nonetheless, the Treasury and the Internal Revenue Service have consistently interpreted the statute as proscribing attempts to influence legislation whether or not such activity is related to the charity's exempt purpose. The Regulations under section $501(\mathrm{c})(3)$ equate legislative activities, regardless of purpose, with "activities not in furtherance of an exempt purpose."12 The Exempt Organizations Handbook expressly states that no distinction is to be made among legislative activities on the basis of the issues involved. ${ }^{13}$

Revenue Ruling 67-29314 clearly illustrates Internal Revenue's position. That ruling held that a nonprofit organization which operates a community facility for the care and protection of stray animals does not qualify for exemption under section 501(c)(3) if, as a substantial part of its activities, it attempts to influence state and local legislation related to the welfare of animals. It is hard to imagine legislative activity more clearly consistent with the charity's exempt purpose. But the ruling rejects the argument that the Code permits advocacy of such legislation and holds that "the statute is quite specific in proscribing, without qualification, substantial legislative activities." 15

made to advance the personal interests of the giver of the money. That is what the commituee were [sic] trying to reach; but we found great difficulty in phrasing the amendment. I do not reproach the draftsmen. I think we gave them an impossible task; but this amendment goes much further than the committee intended to go.

78 Cong. Rec. 5861 (1934).

11. In Seasongood v. Commissioner, 227 F.2d 907, 911 (6th Cir. 1955), Chief Judge Simmons stated his view that the term "propaganda," as used in the statute, "connotes public address with selfish or ulterior purpose." Similarly, in Dulles v. Johnson, 273 F.2d 362, 367 (2d Cir. 1959), the court held that legislative recommendations by an exempt organization are permissible where they "are not intended for the economic aggrandizement of a particular group or to promote some larger principle of government policy."

12. The Regulations provide that an exempt organization is not organized and operated exclusively for one or more exempt purposes if it is authorized to or actually does engage in more than an insubstantial amount of activities which are not in furtherance of an exempt purpose. Treas. Reg. $\S \S 1.501(\mathrm{c})(3)-1(\mathrm{~b})(1)(\mathrm{iii}) .-1(\mathrm{c})(1)(1967)$. They further state that an organization does not meet the organizational or operational tests if it is authorized to or does devote more than an insubstantial part of its activities in attempting to influence legislation. Treas. Reg. $\$ \$ 1.501(c)(3)-\mathbf{i}(\mathrm{b})(3)(\mathrm{i}),-1(\mathrm{c})(3)(\mathrm{ii})(1967)$.

13. IRS, Exempt ORganizations Handbook $\S 363(2)$ (IR Manual No. 7751-1, 1976). In one sense, this position is certainly sound. The distinction between allowed and proscribed legislative activities should not turn on the merits of the legislation involved, since this would place the Internal Revenue in the inappropriate position of deciding whether proposed laws are or are not in the public interest. See Caplin, Limitations on Exempt Organizations: Political and Commercial Activities, in N.Y.U., 8Th Biennial Conference on Charitable Foundations 265, $276-77$ (1967). However, determining whether or not legislative issues are related to a charity's exempt purpose would not require any assessment of the merits of the legislation or of the charity's position. Indeed, an analogous inquiry is required under section 162(e), which allows a business taxpayer to deduct lobbying expenditures with respect to legislation of "direct interest" to it.

14. 1967-2 Cum. Bull. 185.

15. Id. at 186 . 


\section{Regulations Under Section $501(c)(3)$}

The Regulations under section 501 (c)(3) state that an organization which is classified as an "action" organization is not operated exclusively for exempt purposes and, therefore, is not a charity. ${ }^{16}$ An action organization is defined as:

1. An organization which, as a substantial part of its activities, (a) contacts or urges the public to contact members of a legislative body for the purpose of proposing, supporting, or opposing legislation, or (b) advocates the adoption or rejection of legislation; or

2. An organization the primary objective of which can be attained only by legislation and which advocates or campaigns for the attainment of that primary objective. ${ }^{17}$

Thus, under the section 501(c)(3) Regulations an organization may be found to be engaged in legislative activity whenever it proposes legislative change, takes a position regarding the merits of proposed legislation, or advocates social or civic change which would require legislative action. "Legislation" for purposes of the action organization rules is defined as any form of action by Congress, a state legislature, a local governing body, or by the public in the form of a referendum or constitutional amendment. ${ }^{18}$

An example of the sweeping discretion which the Revenue Service has arrogated to itself is its threat in 1963 to revoke the exemption of the Fellowship of Reconciliation, a public charity devoted to world pacifism. The Service at one point concluded that the Fellowship was an action organization because its goal of peace and international reconciliation through love was "political" and attainable only through legislation." Withdrawal from that position followed only after a loud outcry from Congress and the press. ${ }^{20}$

The scope of the definition of legislative activities is limited somewhat by the definition of "charitable" activities. In carrying out a charitable purpose, the Regulations state, an organization is not precluded from advocating social or civic changes or from presenting its opinion on controversial issues; and this may even be done with the intention of molding public opinion or creating public sentiment to an acceptance of its views. ${ }^{21}$ But as this rule applies only to organizations which are not "action" organizations, ${ }^{22}$ the definition is essentially circular and the extent to which it limits the scope of legislative activity is far from clear.

16. Treas. Reg. $\$ 1.501(c)(3)-1(c)(3)$ (1967). An action organization may be eligible for exemption under section 501(c)(4). See Treas. Reg. \$1.501(c)(3)-1(c)(3)(v)(1967).

17. Treas. Reg. $\$ \S 1.501(c)(3)-1(\mathrm{c})(3)(\mathrm{ii}),-1(\mathrm{c})(3)(\mathrm{iv})(1967)$

18. Treas. Reg. $\$ 1.501(c)(3)-1(c)(3)(i i)(1967)$.

19. See Note. The Retenur Corde and a Charitys Politics, 73 YALE L.J. 661, 662-64 (1964).

20. See Caplin, supra note 13, at 270 .

21. Treas. Reg. $\& 1.501(c)(3)-1(d)(2)(1967)$.

22. Id 
Under the Regulations, an "education" organization is permitted to advocate a particular position or viewpoint so long as it presents a sufficiently full and fair exposition of the relevant facts to allow the public to form an independent conclusion. ${ }^{23}$ The mere presentation of unsupported opinion is not education, ${ }^{24}$ but the Service has ruled that a charity's presentation of its viewpoint may be educational although it explicitly favors one side of a controversial issue. ${ }^{25}$

\section{Regulations Under Section 4945}

Section 4945, enacted as a part of the Tax Reform Act of 1969, establishes certain "taxable expenditures" of private foundations, including any amount paid "to carry on propaganda, or otherwise attempt, to influence legislation." ${ }^{26}$ Even an insubstantial amount of legislative activity subjects a private foundation to a penalty excise tax under section 4945; and if such activity is substantial, the foundation may still lose its exemption under section 501 (c)(3). The legislative history of the 1969 Act makes it clear that Congress intended the definition of influencing legislation for purposes of section 4945 to coincide with that under section $501(\mathrm{c})(3) .{ }^{27}$ In light of their more detailed treatment of the issue, the section 4945 regulations are the best available measure of Treasury's current position on the meaning of legislative activity for section $501(\mathrm{c})(3)$ purposes. $^{28}$

The basic definition of legislative activity in these Regulations is essentially the same as that in the section $501(\mathrm{c})(3)$ Regulations:

Direct lobbying. Legislative activity may include direct communication not only with a member or employee of a legislative body, but also with any other government official or employee who might participate in the formulation of legislation. ${ }^{29}$ A public charity may therefore find itself engaged in proscribed

23. Treas. Reg. § 1.501(c)(3)-1(d)(3)(i) (1967); see Rev. Rul. 79, 1970-1 Cum. Bull. 127; Rev. Rul. 195. 1964-2 Cum. Bull. 138.

24. Treas. Reg. $\$ 1.501(c)(3)-1(d)(3)(i)$ (1967).

25. See Rev. Rul. 192, 1964-2 Cum. Bull. 136 (better radio and TV programming); Rev. Rul. 195, 1964-2 Cum. Bull. 138 (court reform); Rev. Rul. 70, 1968-I Cum. Bull. 248 (minority employment). But of. League of Women Voters v. United States, 180 F. Supp. 379, 383 (Ct. Cl. 1960) (forum discussions by members in formulating position to be taken on questions of public interest constituted "preparation for the influencing of legislation" and were, therefore, legislative activities)

26. Pub. L. No. 91-172, §101(b), 83 Stat. 512.

27. See, eg., Staff of the Joint Comm. on Internal Revenue Taxation, 9 lst Cong., 2d Sess., General Explanation of the Tax Reform Act of 1969, at 47, 49 (Comm. Print 1970): Prior law (sec, $501(\mathrm{c})(3)$, unchanged by the Act) requires that no substantial part of the activities of a private foundation may consist of carrying on propaganda or otherwise attempting to influence legislation ... Essentially, the provision removes the "substantiality" test in determining whether a private foundation has made a taxable expenditure in this area.

28. Se Haswell v. United States, 500 F.2d 1133, 1143 (Ct. Cl. 1974).

29. Treas. Reg. $\$ 53.4945-2(c)$ (1972). 
activity if it contacts an official of the executive branch of the federal, state, or local government to recommend official action which would require legislation. ${ }^{30}$

Grassroots lobbying. Legislative activity may also include any attempt to affect the opinion of the general public or any segment thereof for the purpose of influencing legislation. Such "grassroots" lobbying includes publicly advocating adoption or rejection of specific legislative proposals as well as urging the public to contact legislators about legislation being considered by, or to be submitted imminently to, a legislative body. ${ }^{31}$

The most important aspect of the section 4945 Regulations is that they set forth, for the first time, four explicit exceptions to the definition of legislative activities. These exceptions, based on language in section 4945 and in the legislative history of the $1969 \mathrm{Act}$, are intended both to limit and to clarify the scope of the restriction. ${ }^{32}$

Nonpartisan analysis, study, and research. Legislative activity does not include engaging in nonpartisan analysis, study, or research and making the results thereof available to the public through publications, speeches, conferences, and dissemination to news media. ${ }^{33}$ Such analysis, study, or research may advocate a particular viewpoint or comment on the merits of proposed legislation so long as (1) it presents a sufficiently full and fair exposition of the facts to enable the public to reach an independent opinion or conclusion, ${ }^{34}$ and (2) the results of the analysis, study, or research are not presented only to persons interested in one side of the issue. ${ }^{35}$

This exception suggests that charities may actively support or oppose legislation so long as they appeal to reason rather than emotion and so long as their views are accompanied by a fair presentation of the facts and a reasoned exposition of the supporting arguments. Representatives of exempt organizations commenting on the proposed Regulations under section 4945 urged the Treasury to state so explicitly in the final Regulations. But despite some important changes in the final Regulations' definition of nonpartisan analysis,

30. The Regulations state that legislative activity does not include any attempt to persuade an executive body, for example, to form, or acquire property for use in, a public park or preserve established or to be established by Congress or by a state or local legislature. Legislative activity would include, however, an attempt to persuade any government official or employee to promote the legislative authorization or appropriation of funds for such an acquisition. Treas. Reg. $\$$ $53.4945-2(\mathrm{a})(2)(1972)$.

31. Treas. Reg. $\$ \$ 53.4945-2(a)(1),-2(b)(1972)$.

32. See Staff of the Joint Comm. on Internal Revenue Taxation, supra note 27, at 48-49. The Assistant Secretary of the Treasury for Tax Policy suggested that the exceptions contained in the sectioin 4945 Regulations are the most liberal interpretation of permissible activities which is consistent with the statute and its legislative history. Testimony of Edwin S. Cohen, in Hearings on Legislative Activity by Certain Types of Exempt Organizations Before the House Comm. on Ways and Means, 92d Cong., 2d Sess. 5-6, 12 (1972).

33. Treas. Reg. $\$ 53.4945-2$ (d)(1) (1972); $c$. Treas. Reg. $\$ 501(c)(3)-1(d)(3)(i)(1967)$.

34. Treas. Reg. $\$ \$ 53.4945-2(d)(1)(i i),-2(d)(1)(v)$, examples $(1)-(3)(1972)$.

35. Treas. Reg. $\$ 53.4945-2$ (d)(1)(iv) (1972). 
study, and research, the Treasury failed to provide explicitly that nonpartisan analysis, study, and research may be addressed to the merits of specific legislative proposals. As a result, although this exception liberalizes and clarifies the legislative activity rules, it leaves substantial areas of uncertainty for charities attempting to determine what forms of analysis, study, and research on legislative issues are or are not subject to challenge.

Technical advice or assistance. Legislative activity does not include providing technical advice or assistance to a governmental body in response to a written request by such body. ${ }^{36}$ This exception, though clearly and objectively defined, is quite narrow. The request must be made in the name of the governmental body as a whole, not one or more individual members, and the organization's response may not go beyond the scope of the request for technical advice. ${ }^{37}$ Under the section 4945 Regulations no latitude is given to charities to express their opinions or make recommendations on the merits of proposed legislation unless specifically requested.

Direct lobbying on issues related to exempt status. Legislative activity does not include communication with or appearance before a legislative body with respect to legislation which might affect the existence, powers, duties, or tax exempt status of the organization. ${ }^{38}$ This exception was recognized by the Service prior to the promulgation of the section 4945 Regulations $^{39}$ and does not change the prohibition against supporting or opposing legislation affecting the organization's charitable purposes and programs. ${ }^{40}$

Discussion of broad social or economic problems. Legislative activity does not include public discussion or communication with legislators or other government employees on broad social and economic problems so long as the discussion does not address itself to the merits of a particular legislative proposal. ${ }^{41}$ This exception, like that for nonpartisan analysis, study, or research, was intended to liberalize the legislative activity rules. The legislative history of the 1969 Act supports the view that a charity is limited only in its participation in the process of formulating specific legislative proposals, and that it is otherwise free to discuss social or economic issues with legislators and others and to give information, express opinions, and advocate particular approaches or solutions. ${ }^{42}$ But the language of the Regulations is ambiguous and might be

\footnotetext{
36. Treas. Reg. $\$ 53.4945-2(\mathrm{~d})(2)(1972)$.

37. Treas. Reg. $\$ 53.4945-2(d)(2)($ i). $-2(d)(2)(i i),-2(d)(2)($ iii), example (2) (1972).

38. Treas. Reg. \$ 53.4945-2(d)(3) (1972).

39. Rev. Rul. 449, 1970-2 Cum. Bull. 112.

40. Legislation related to exempt status is narrowly defined by the Regulations. For example, it does not include legislation adopting or terminating government programs which would affect the scope of the charity's future activities. Treas. Reg. $\$ 53.4945$-2(d)(3)(ii), examples (3), (4) (1972).

41. Treas. Reg. \$ 53.4945-2(d)(4) (1972)

42. She Staff of the Joint Comm. ON Internal Revenue Taxation, supro note 27 , at 49 :
}

[T]he Act precludes direct attempis to persuade members of legislative bodies or gov- 
interpreted by the Revenue Service as allowing only abstract discussion of "problems" while barring advocacy of particular approaches to legislative solution of such problems. The Regulations, therefore, fail to eliminate an important area of uncertainty about what types of discussion of social or economic problems might be considered legislative activity.

In the section 4945 Regulations, the Treasury has undertaken both to clarify and to limit the definition of legislative activity and to provide explicitly defined "safe havens" - that is, categories of activities which involve legislative matters or issues but are not "attempting to influence legislation" for purposes of the section 4945 excise tax or the section 501 (c)(3) substantiality test. Thus the section 4945 Regulations provide charities with substantially greater certainty about some questions left unanswered in the section $501(c)(3)$ Regulations. They explicitly allow charities to present testimony to a legislative body in response to an express invitation and to lobby for or against legislation affecting the organization's existence or exempt status. And they permit activities which fall within the general concepts of "nonpartisan analysis, study, or research" and "examination and discussion of broad social and economic problems." These exceptions can properly be interpreted as allowing a broad range of communication about legislative issues. But in the absence of more adequate standards or guidelines, the Regulations continue to leave important questions unanswered and, in some areas, fail to provide a charity with reasonable certainty that actions which it concludes are within an exception will not be challenged as legislative activities by a revenue agent.

\section{B. The Substantiality Test}

Present law allows a public charity to engage in legislative activities so long as they do not constitute a "substantial" part of its overall program. But the Code provides no guidance on how substantiality is to be determined and the Regulations merely rephrase the statute by requiring that legislative activities be "insubstantial." 43 The burden of giving content to the substantiality test has devolved on the Internal Revenue Service and the courts which, instead of establishing objective or quantitative standards, have adopted a qualitative approach requiring consideration of all the surrounding facts and circumstances in each case. This nebulous test has proven unsatisfactory both to the Revenue Service, which faces almost insuperable administrative difficulties in attempting to apply the law evenhandedly, and to the charities, which have no

ernment employees to take particular positions on specific legislative issues. . . [T] provision ... does not prevent the examination of broad social, economic, and similar problems of the type the government would be expected to deal with ultimately, even though this does not permit lobbying on matters which have been proposed for legislative action.

43. Treas. Reg. $\$ \S 1.501(c)(3)-1(b)(1)(i)(b),-1(c)(1)(1967)$. 
way of determining in advance what amount of legislative activity is permissible.

\section{Quantitative vs. Qualitative Test}

The few decided cases interpreting the substantiality test have further confused rather than clarified the issue. In Seasongood $v$. Commissioner of Internal Revenue, ${ }^{44}$ the Sixth Circuit Court of Appeals held that an organization's legislative activities were not substantial where less than five per cent of the "time and effort" of its members was devoted to influencing legislation. ${ }^{45}$ Seasongood was cited with approval in Dulles $v$. Johnson, ${ }^{46}$ in which the Second Circuit held that bequests to certain bar associations were deductible because "approval of or opposition to proposed legislation constitutes but a small portion of the total activity of the Associations." 47 But some courts have rejected this quantitative approach. For example, in Krohn $v$. United States, ${ }^{\mathbf{4 8}}$ the court refused to follow Seasongood-although it recognized that a quantitative test entailed desirable simplicity and certainty-on the ground that such a test "obscures the basic difficulties of balancing activities in the context of organizational objectives and circumstances." The court went on to suggest (1) that the meaning of "substantial" may vary with different types of organizations, and (2) that the amount of legislative activity which is substantial may depend in part on the extent of the organization's noncharitable activities which do not involve attempts to influence legislation. ${ }^{49}$

The Internal Revenue Service has expressly disavowed the quantitative test of Seasongood in favor of a qualitative test which requires analysis of all the organization's expenditures and activities in light of various factors, including those suggested in Krohn. ${ }^{50}$ In a 1966 letter proposing revocation of the Sierra Club's tax exemption on the basis of its legislative activities, the Internal Revenue Service stated that the dollar amounts expended for such activities were relevant to its determination but not controlling. ${ }^{51}$ In testimony before the House Appropriations Committee in 1968, the Commissioner of Internal Revenue rejected a flat percentage test, whether the five per cent suggested in Seasongood or even one per cent. He then identified some of the factors that the Service might consider in determining substantiality-including the amounts of money spent on legislative activities, the amount of time devoted

\footnotetext{
44. 227 F.2d 907 (6th Cir. 1955).

45. Id. at 912 .

46. 273 F.2d 362 (2d Cir. 1959).

47. Id. at 367 .

48. 246 F. Supp. 341, 347-48 (D. Colo. 1965).

49. 246 F. Supp. at $348-49$.

50. The rejection of a quantitative test was approved in Christian Echoes Nat'l Ministry $v$. United States, 470 F.2d 849 (10th Cir. 1972), cert. denied, 414 U.S. 864 (1973).

51. Letter from Joseph M. Cullen, District Director of Internal Revenue to the Sierra Club, Dec. 16, 1966, in CCH 1967 STAND. Fed. TAX. ReP. $(67-7$ at 71,380$) \$ 6376$.
} 
to such activities by employees and unpaid volunteers, the relative budgets for legislative activities and other activities, and an undefined concept referred to as the organization's "real activity." 52

In determining the substantiality of an organization's legislative activities, the Revenue Service thus scrutinizes a mixture of qualitative and quantitative factors. In its Exempt Organizations Handbook, the Service states that: "There is no simple rule as to what amount of activities is substantial. The one case on the subject [Seasongood] is of very limited help." ${ }^{53}$ The Handbook then sets forth a "definition of substantial" which provides little guidance: ${ }^{54}$

Most cases have tended to avoid any attempt at percentage measurements of activities. The central problem is more often one of characterizing the various activities as attempts to influence legislation. . . . Once that determination is made, substantiality is frequently self-evident.

\section{Allocation of Support Activities}

An important issue raised by this largely qualitative approach is the extent to which a charity's overall administrative, educational, or research activities will be considered in determining the substantiality of its legislative activities. In Kuper \%. Commissioner of Internal Revenue, ${ }^{55}$ the Service had disallowed the taxpayer's deduction of contributions to a local chapter of the League of Women Voters because of its legislative activites. The court found that an "insignificant part ... of the activities of the League consists of writing, telegraphing or telephoning to representatives in Congress and the state legislature, testifying before legislative committees, and like direct efforts to influence legislation." Nonetheless, it held that the League's legislative activities were substantial because "a very substantial portion" of the League's activities consisted of "formulating, discussing and agreeing upon the positions, if any, to be taken with respect to advocating or opposing legislative measures," and that such activities "are an essential part of the general legislative program of the League." 56

The Revenue Service has seized upon the rationale of Kuper and views the characterization of supporting activities as a "central" consideration in the application of the substantiality test: ${ }^{57}$

In determining substantiality, it is sometimes difficult to determine what supporting activities should be included with the proscribed attempts to influence

52. Hearings on Treasury Dep't and Related Agencies Appropriations for 1968 Before a Subcomm. of the House Comm. on Appropriations, 90th Cong., 1st Sess. 536 (1967). See Caplin, supra note 13, at 273-74.

53. EXempt ORganizations Handbook, supra note $13, \S 364(1)$.

54. Id. $\$ 364(2)$.

55. 332 F.2d 562 (3d Cir. 1964).

56. 332 F.2d at 562-63; $c f$. Liberty Nat'l Bank \& Trust Co. v. United States, 122 F. Supp. 759

(W.D. Ky. 1954).

57. EXEMPt ORganizations Handbook, supra note 13 , § 364(2). 
legislation. This is often a problem when an organization has some activities that are admittedly educational. Frequently, much effort is devoted to research, discussion, and similar activities. The problem is how much of these backup activities should be considered part of the attempts to influence legislation. ... Attempting to influence legislation does not necessarily begin at the moment the organization first addresses itself to the public or the legislature. ${ }^{58}$

This issue is of great practical importance to charities which undertake any legislative activities. The language of the Exempt Organizations Handbook appears to imply that activities which, considered alone, are educational or charitable might nonetheless be taken into account in assessing the substantiality of a charity's legislative activities. To date, the Service has not made public any guidelines or standards for determining whether or when supporting activities which are not in themselves attempts to influence legislation will be taken into account. This, too, is apparently viewed as a question of fact to be decided on a case by case basis.

\section{Effects of the Restriction}

Ignoring for the moment the public policy issues involved in excluding public charities from the legislative process, the present provisions are unsatisfactory on practical and administrative grounds. Revenue agents charged with applying the standards evenhandedly to thousands of exempt organizations are faced with an overwhelming task. To determine whether a particular charity is engaged in substantial legislative activities, an agent theoretically must make an intensive investigation into all aspects of the organization's expenditures and activities. He must make difficult and largely subjective determinations including (1) whether opinions expressed by the organization constituted the results of nonpartisan analysis, study, or research and were accompanied by a "full and fair exposition" of relevant facts; (2) whether communications with legislators addressed "broad social or economic issues" or involved formulation of specific legislative proposals; and (3) whether public statements and publications of the charity were intended to influence public opinion about specific legislation. He must also decide which research, educational, and administrative activities are to be weighed as "supporting activities" and which volunteer activities by members or others are to be attributed to the organization. Finally, he must decide, on the basis of all the facts and circumstances and with no meaningful quantitative guidelines, whether the organization's proscribed activities are "substantial."

These generalized standards confer on the Internal Revenue Service a discretion that is overly broad-particularly when exercised in the context of an organization's total activities, which may involve matters of sociology, economics, international relations, political theory, finance, religion, and the

58. Id. \& 362 . 
whole range of human knowledge. This type of discretion lends itself to charges of selective application of the law; and various allegations have been made that revenue agents and district directors have subjectively and discriminatorily enforced the restriction to suppress the views of organizations with which they disagree. ${ }^{59}$ Whether or not these allegations are well founded, such discretion and the resulting potential for actual or apparent abuse are undesirable as a matter of sound tax administration.

Furthermore, the difficulties involved in applying the standard and the limited resources available to IRS district offices make a certain amount of selective enforcement inevitable. ${ }^{60}$ In practice, investigations tend to be undertaken when an organization makes an unusually visible or successful attempt to influence legislation. For example, the Sierra Club, which ultimately lost its exemption, was investigated primarily as a result of its 1966 advertising campaign to block legislation for construction of the Grand Canyon dam. That campaign involved only about ten thousand dollars, an insignificant part of the club's annual budget. ${ }^{61}$

Ultimately, the principal victims of the vagueness and ambiguity of the present law are public charities attempting in good faith to comply with the legislative activity restriction. The Code allows a charity to become involved in the legislative process so long as such activities are not a substantial part of its charitable program. But a charity must first attempt to determine what sorts of activities constitute attempts to influence legislation, then predict what amounts of such activities would be considered substantial. ${ }^{62}$ Furthermore, the penalty for engaging in substantial legislative activities-loss of both the section 501(c)(3) exemption and the crucial right to receive deductible contributions-is tantamount to a death sentence. ${ }^{63}$ The organization might be able to secure tax exemption under section $501(\mathrm{c})(4),{ }^{64}$ but without the right to receive deductible contributions its source of funds to carry on its charitable program would largely dry up. ${ }^{65}$

59. Hearings on H.R. Res. 803 Before the House Comm. on the Judiciary, 93d Cong., 2d Sess., Statement of Information, bk. VIII, at 80, $87-88$ (1974); S. Rep. No. 552, 9 lst Cong., 1st Sess. 47 (1969); see Borod, supra note 8, at 1105-06. See also Christian Echoes Nat'l Ministry v. United States, 470 F.2d at 853, 857-58 (10th Cir. 1973).

60. See Borod, supra note 8, at 1103-06.

61. See Note, supra note 8 , at $1122-23$.

62. It would presumably be possible for a charity to secure an advance ruling on whether a particular activity would or would not fall within the proscription, but obtaining such rulings prior to each questionable action would be impractical and expensive. Furthermore, the Service would certainly decline to rule in advance on the substantiality question, which is inherently an issue of fact. See Treas. Reg. $\S 601.201$ (d) (1973).

63. See "Americans United" Inc. v. Walters, 477 F.2d 1169, 1177 (D.C. Cir. 1973), rev'd sub. nom. Alexander v. "Americans United" Inc., 417 U.S. 752 (1974).

64. Treas. Reg. $\$ 1.501(c)(3)-(c)(3)(v)(1967)$.

65. See Parker, Relations with the Internal Revenue Service: Exemption, Application and Audit, in N.Y.U., 9th Biennial Conference on Charitable Foundations 223, 240-41 (1969). 
A conservatively run public charity will normally endeavor to stay well within the substantiality rule, and under present law the only means of doing so is either to forgo entirely or to strictly limit participation in the legislative process. ${ }^{66}$ In practice, the in terrorem effect of the vague statutory proscription causes many charities to avoid most direct or indirect efforts to support or oppose legislation, even when the legislation is directly related to the charitable purposes for which they are organized and operated.

II

\section{Public Policy Considerations}

Our discussion above centered on the practical and administrative difficulties that flow from the vagueness of the existing restriction on legislative activities by public charities. Although highly significant, they are only part of the problem. Sound public policy requires that the restrictions be not only clarified but also liberalized to allow public charities to participate freely and openly in the legislative process.

A. Legislative Activity is a Legitimate Means by

Which a Charity Can Pursue Its Exempt Purposes

The limitation on legislative activity by charitable organizations has been justified on grounds that exempt organizations should be restricted to charitable or educational purposes and that legislative activity is neither education nor charity. ${ }^{67}$ But this argument confuses the goals of an exempt organization with the means it may employ to achieve those goals. No sound public policy justifies blanket restrictions on a public charity's use of legislative activity as a means to achieve its legitimate goals.

To qualify for tax exemption, a charity must be organized and operated exclusively for one or more of the exempt purposes specified in the Code. ${ }^{68}$ Its goals and programs must relate to the public interest rather than the private interests of any individual or group. ${ }^{69}$ Other than a prohibition against intervention in political campaigns ${ }^{70}$ and the restriction on legislative activities, the tax law places no limitations on the means a charity may employ in pursuing its legitimate goals. It can engage in study, research, education, and even advertising to increase public awareness of a social problem. It can take direct action to alleviate such problems through programs of its own. It can coordi-

66. For a list of practical suggestions to charities for avoiding possible challenge under the existing legislative restrictions see Caplin, supra note 13, at 279-80.

67. See Slee v. Commissioner, 42 F.2d 184, 185 (2d Cir. 1930).

68. Treas. Reg. $\$ 1.501(\mathrm{c})(3)-1$ (d)(1)(i) (1967).

69. Treas. Reg. $\S 1.501(\mathrm{c})(3)-1(\mathrm{~d})(\mathrm{l})(\mathrm{ii})(1967)$.

70. Section $501(\mathrm{c})(3)$ prohibits even insubstantial amounts of political campaigning by exempt organizations on behalf of any candidate for public office. Treas. Reg. §501(c)(3)-1(c)(3)(iii) (1967) 
nate the efforts of individuals and organizations directed at solving those problems. It can attempt to convince government agencies to take or refrain from taking action affecting its exempt purposes. And it can use the judicial process either to compel private parties or government officials to comply with existing laws or to challenge laws or administrative actions as invalid or unconstitutional.

But a public charity is effectively denied access to the legislative process -whether to secure governmental assistance in pursuing its charitable purposes, to remove statutory barriers to accomplishing its goals, or even to induce the government to respond to public rather than private interests. Ironically, as a result of the expansion of the concept of charity and the increasing involvement of the government in areas traditionally left to private philanthropy, this means foreclosed to public charities is often a necessary part of an effective charitable program. ${ }^{71}$

Issues affecting public charities and the goals they seek to achieve are the subjects of legislative proceedings at all levels of government. For example, the goals of charities devoted to health research and the provision of health care are vitally affected by legislative decisions on government support for health research programs and by legislative programs regulating health care or ensuring adequate health care to groups such as the poor and aged. The programs of educational institutions and charities devoted to improving the quality of public education can be advanced or thwarted by legislative action at the federal, state, or local levels. Similarly, myriad legislative actions have an impact on the goals of charities devoted to consumer protection or individual safety.

Furthermore, many important charitable goals can be achieved only with the aid of legislation. For example, enhancement of the natural environment, preservation of wilderness areas, and protection of wildlife are generally recognized as legitimate and important charitable purposes. Numerous organizations formed to pursue such goals have been held exempt under section $501(\mathrm{c})(3)$ and have received broad public support. Although nonlegislative activity-including direct action, study, research, and educational activities - play an important part in the charitable programs of such organizations, legislation is often equally important. Ultimately, air, water, and noise pollution can be effectively controlled or abated only through governmental intervention; government authorization and appropriations are a prerequisite to significant steps toward wilderness preservation; and federal or state legislation must play a part in the protection of endangered wildlife.

In brief, the legislative chambers may, at any given time, be the focal point of actions or controversies vitally affecting a charity's programs and goals. If

71. See generally Clark, supra note 8, at 454; Sacks, The Rols of Philanthropy: An Institutional View, 46 VA. L. Rev. 516, 519-24 (1960). 
public charities are to be a part of our national life, and they are, what valid policy reason can there be for denying them free access to the legislative process?

\section{B. Charities Can Provide Expertise and an Otherwise Unrepresented Point of View in the Process of Formulating Legislation}

It is fundamental to our pluralistic, democratic system of government that legislation is formulated to the maximum extent possible through consideration of all available data and of the opinions and viewpoints of all interested parties. This process requires exchanges between legislators and private individuals or groups who are informed on the issues or who will be affected by the proposed legislation. Within this framework, exempt organizations are uniquely situated to provide valuable assistance to legislators.

Some issues which are the subject of legislation relate to social problems that public charities have dealt with for many years. Long before environmental protection and wilderness preservation became important political issues, exempt organizations such as the Sierra Club, the National Audubon Society, and others were conducting research on the effects of man on his environment, educating the public to the problems of pollution and over-exploitation of natural resources, and taking direct action to preserve and protect wilderness areas. Similarly, exempt organizations engaged in programs to improve the quality of education or health care or to alleviate poverty are in a position to understand the nature of the problems, evaluate the impact of proposed solutions, and give valuable guidance regarding practical and administrative difficulties which may arise in implementing a proposed program.

Legislators dealing with such social problems should have the information and expertise of charities which have practical experience in the field and have manifested by their activities awareness and concern about the issues involved. Yet under present law a charity cannot offer information or views without jeopardizing its tax exemption. The Regulations' narrow exception allowing charities to present "technical advice" in response to a specific request from a legislative body is no answer to the problem. ${ }^{72}$ It is unrealistic to assume that legislators will be in a position to predict what organizations might have valuable information on every issue.

In addition to the information and expertise they can offer, public charities can serve a valuable function as spokesmen for otherwise unrepresented points of view. Businesses and other private interests which will sustain

72. As discussed above, the Regulations under section 4945 allow the presentation of technical advice and assistance in response to a direct invitation by a legislative body; this exception does not extend to responses to a general solicitation of the views of the public. See Treas. Reg. $\S 53.4945-2(d)(2)(1972)$. 
a benefit or detriment from proposed legislation have an economic incentive to make their views known to the legislature, ${ }^{73}$ and such views are certainly relevant. But it is also important that legislators consider the views of groups concerned about equally relevant public interest issues.

In testimony before the House Ways and Means Committee, a representative of the National Association for Mental Health presented a compelling example of the importance of a charity as public interest spokesmen for an otherwise unrepresented viewpoint: ${ }^{74}$

Because the rights of patients, the quality of their care, and the funds available for treatment are primarily determined by actions taken by city, county, State, and Federal legislators-the mental health association, as the principal advocate of the mentally ill, has an obligation to speak before these legislative bodies regarding the needs of these individuals. To deny the mental health association the opportunity to fulfill its obligation is to condemn the mentally ill to the abuse and neglect which has characterized the past.

Senator Muskie addressed a similar concern in a statement accompanying the introduction in 1971 of a bill to liberalize the legislative activity limitations: ${ }^{75}$

The groups which suffer most under these limitations of the Internal Revenue Code are civil rights organizations, consumer and environmental groups, and the recently established public interest law firms. The outstanding characteristic of these groups has been their advocacy of the views of those who are under-represented before governmental agencies, in the courts, and Congress. It is fundamental to our constitutional system that they should have equal access along with business groups and others presenting views to Congress.

The information and viewpoint that public charities can provide legislators is not necessarily more valuable or more important than those of other individuals or interest groups. But in the give-and-take of the legislative process, it is unreasonable as a matter of public policy to exclude entirely both a source of information and a viewpoint which could materially aid legislators in balancing the conflicting public and private interests affected by their actions.

\section{The Restriction Unfairly Discriminates Against Public Charities}

At the time that the prohibition against legislative activity by charities was added to the Code, it was arguably supportable on the ground of a congressional policy against subvention by the government of lobbying activity. ${ }^{76}$

73. As discussed below, many lobbying expenses incurred by such individuals or groups are tax deductible. See text accompanying notes 77-85 infra.

74. Testimony of Jeanette Rockefeller, in Hearings on Legislative Activity by Certain Types of Exempt Organizations, supra note 32, at 83.

75. 117 Cong. Rec. 8517 (1971).

76. See, e.g., Slee v. Commissioner, 42 F.2d 184, 185 (2d Cir. 1930). 
Neither businesses nor individuals were entitled to deduct the costs of attempts to influence legislation, and the argument was made that the Treasury should stand neutral and require all taxpayers to bear the full cost of their lobbying activities. ${ }^{77}$ However valid that argument may have been in 1934 , it is untenable today; for under present law, a wide range of organizations can conduct direct lobbying and sometimes grassroots lobbying with tax deductible and tax exempt funds.

In 1962, Congress enacted Code section 162(e), which represents a clear departure from the policy against government support of lobbying expenses. ${ }^{78}$ That section allows a business taxpayer to deduct expenses incurred in communicating with or appearing before legislative bodies to influence legislation of direct interest to it. ${ }^{79}$ Section $162(\mathrm{e})$ does not allow deductions for grassroots lobbying, but as a practical matter, except in the most egregious cases, expenses incurred in attempting to influence legislation by affecting the views of the general public are deductible as institutional advertising expenses. ${ }^{80}$ Thus, since 1962 businesses and individuals have been relatively free to use tax deductible funds to lobby for or against legislation affecting their economic interest, while public charities continue to be barred from representing public or charitable interests. Commentators have discussed at length the fact that such discrimination against public charities is indefensible as a matter of equity and public policy. ${ }^{81}$ The then chairman of the President's Council on Environmental Quality emphasized the point in his testimony before the House Ways and Means Committee on a proposed bill to liberalize the legislative activity restrictions: ${ }^{82}$

It is clear that both business and administrative agencies have open access to the legislature. Thus, the present situation has the practical effect of discriminating against section $501(\mathrm{c})(3)$ organizations. So long as there is a threat hanging over our public charitable bodies that they will lose their favored tax status if they present their case on issues related to their purposes to the legislature, the legislature is not getting the full picture.

In addition to businesses, numerous other organizations are allowed to lobby with tax deductible or tax exempt funds. Contributions to veterans' or-

77. Cammarano v. United States, 358 U.S. 498, 512 (1959).

78. Revenue Act of 1962, Pub. L. No. 87-834, § 3(a), 77 Stat. 973

79. One of the principal reasons cited by the Senate Finance Committee Report in support of the statute was that " $[\mathrm{t}] \mathrm{he}$ presentation of such information to the legislators is necessary to a proper evaluation on their part of the impact of present or proposed legislation." S. Rep. No. 1881, 87th Cong., 2d Sess. 22 (1962).

80. Testimony of Edwin S. Cohen, Mortimer M. Caplin, and George Cooper, in Hearings on Legislative Activity by Certain Types of Exempt Organizations, supra note 32, at 17-20, 35-36, 259-60.

81. See, e.g., Garrett, Federal Tax Limitations on Political Activities of Public Interest and Educational Organizations, 59 GEO. L.J. 561, 583-85 (1971); Geske, Direct Lobbying Activites of Public Charities, 27 TAX LAWYER 305 (1972).

82. Testimony of Russell Train, in Hearings on Legislative Activity by Certain Types of Exempt Organizations, supra note 32 , at 28. 
ganizations and fraternal benefit societies are deductible for income and gift tax purposes $^{83}$ and such organizations are themselves made tax exempt by sections 501(c)(19) and 501(c)(8) respectively. But except for deductions for estate tax purposes, the Code and Regulations do not limit the rights of these organizations to engage in direct or grassroots lobbying. ${ }^{84}$ There are thousands of such organizations in this country, including the Veterans of Foreign Wars, the American Legion, the Masons, Elks, and so forth. Many are deeply involved in influencing legislation and spend substantial amounts each year for the purposes of communicating their members' views to legislative bodies, urging their members to support or oppose legislation, and influencing the opinion of the general public. ${ }^{85}$ Funds so expended are tax deductible by the donor and tax exempt in the hands of the organizations.

\section{The Present Restrictions Raise Serious \\ Questions of Constitutionality}

The first amendment to the Constitution guarantees the right to free speech and the right to petition the legislature for redress of grievance. Tax provisions which prohibit charities from attempting to influence legislation and which discriminate among charitable organizations on the basis of their free speech and petition activities are clearly at cross-purposes with the policy of the first and fifth amendments. In a recent article on the subject, Thomas Troyer presented a strong case that the restrictions are unconstitutional. ${ }^{86}$ These constitutional issues have not been definitely resolved in any court and have not been addressed by the Supreme Court.

The initial constitutional challenge is based on the doctrine of unconstitutional conditions. A charity's rights of free speech and to petition the legislature are protected from government infringement by the first amendment. ${ }^{\mathbf{8}}$ Just as it cannot directly prohibit first amendment activity, Congress may not-at least in the absence of a compelling government interest-inhibit such

83. Veterans' organizations: sections $170(c)(3), 2522(a)(4),-(b)(5)$; fraternal benefit societies: sections $170(\mathrm{c})(4), 2522(\mathrm{a})(3),-(\mathrm{b})(4)$. The estate tax provisions of the Code allow a deduction for bequests only to veterans' organizations incorporated by an Act of Congress. INT. REv. Code of 1954 , $\$ 2055(a)(4)$. Bequests to fraternal benefit societies are deductible for estate tax purposes. Id. $\$ 2055(\mathrm{a})(3)$. But see note 84 infra.

84. Id. $\$ 2055(\mathrm{a})(3)$ allows a deduction for estate tax purposes of a bequest to a fraternal benefit society only if "no substantial part of the activities of such . . . society . . . is carrying on propaganda, or otherwise attempting, to influence legislation." No analogous restriction is contained in the provisions allowing income and gift tax deductions for contributions to such societies or to veterans' organizations.

85. See Troyer, Charities, Lawmaking and the Constitution: The Validity of the Restrictions on Influencing Legislation, in 31 N.Y.U. InsTITUTE ON FED. TAXATION 1415, 1438-42 (1973).

86. See generally id.

87. The Supreme Court has held that the first amendment protects the rights of corporations as well as individuals. Grosjean v. American Press Co., 297 U.S. 233, 244-45 (1936); see New York Times v. Sullivan, 376 U.S. 254 (1964). 
activity indirectly by conditioning a tax benefit or other valuable privilege on the recipient's willingness to forgo its constitutional rights. ${ }^{88}$ The restriction on legislative activities places just such a condition on a public charity's exempt status. A charity may enjoy the benefits of tax exemption under section $501(c)(3)$ and the right to receive tax deductible contributions only so long as it refrains from substantial attempts to influence legislation. If it chooses to engage in the legislative process, the charity forfeits the right to favorable tax treatment. Moreover, no compelling interest supports the restriction on legislative activities by public charities. Any possible interest deriving from a governmental policy against public subvention of lobbying activities was abandoned with the passage of section 162(e), allowing business tax deductions for lobbying expenses; and the existence of such a government policy is further negated by the fact that the Code allows many other types of organizations to lobby with tax exempt or tax deductible funds. ${ }^{89}$

Second, the restriction on legislative activities appears to violate the equal protection standards of the due process clause of the fifth amendment. The Code treats certain charities unfavorably solely on the basis of their first amendment activity. Such discrimination-through a statutory classification which is based on the exercise of constitutionally protected rights-is constitutional only if it serves a legitimate and compelling government interest. ${ }^{90}$ As discussed above, no such governmental interest appears to support the selective denial of tax benefits to charities engaging in substantial attempts to influence legislation.

Third, the restriction on legislative activity, even if supported by a compelling government interest, would be of doubtful constitutionality by virtue of the breadth and vagueness of the statutory prohibition. The Supreme Court has held in various contexts that statutes which directly or indirectly proscribe first amendment activities must be drafted with narrow specificity in order that one need not guess whether or not his conduct falls within the statutory bar. ${ }^{91}$ The restriction on legislative activity by exempt organizations is so broad and vague that it is often difficult for a charity to determine even whether a particular activity constitutes an attempt to influence legislation, and it is virtually never possible for a charity to predict how much activity it may engage in before influencing legislation becomes "substantial." Because of this and because of the harshness of the penalty imposed, most public charities have felt constrained to avoid activities which might be construed as attempts to influence legislation. Thus, the statutory prohibition has in fact had the sort of "chilling effect" on the exercise of first amendment rights

\footnotetext{
88. Speiser v. Randall, 357 U.S. 513,518 (1958).

89. Cf. Police Dep't of Chicago v. Mosley, 408 U.S. 92 (1972).

90. See Dunn v. Blumstein, 405 U.S. 330, 335-39 (1972).

91. See generally Note, The Void-for-Vagueness Doctrine in the Supreme Court, 109 U. PA. L. REV. $67(1960)$.
} 
which has led the Supreme Court to strike down other statutes as unconstitutionally vague. ${ }^{92}$

Constitutional challenges to the restrictions on legislative activity by public charities have been raised in four recent cases. In "American United" Inc. $v$. Walters, ${ }^{93}$ an organization which had lost its tax exempt status as a result of legislative activity argued that the Revenue Service's revocation of its right to receive deductible contributions constituted unconstitutional discrimination because a larger organization could carry on the same amount of legislative activity without jeopardizing its exemption. ${ }^{94}$ The United States Court of Appeals for the District of Columbia Circuit held that the organization had raised a substantial constitutional issue and remanded the case to the district court with instructions to convene a three-judge panel. ${ }^{\mathbf{5}}$ However, the Supreme Court reversed the court of appeals on the ground that the action was barred by the Anti-Injunction $\mathrm{Act}^{96}$ as a suit to restrain the collection of a $\operatorname{tax} .^{97}$

In Christian Echoes National Ministry v. United States, ${ }^{98}$ a religious organization which had lost its tax exempt status as a result of allegedly substantial legislative activity, argued that the statutory limitation, as applied to its activities, violated the free exercise of religion clause of the first amendment. The district court agreed, ${ }^{99}$ but the Tenth Circuit Court of Appeals reversed, holding that the restriction does not violate the free exercise clause. ${ }^{100} \mathrm{Al}$ though the issue was not raised or briefed by either party, the appellate court went on to state, without analysis or citation of authority, that the legislative activity restriction does not deprive the organization of its right to free speech because "tax exemption is a privilege, a matter of grace rather than a right."101 The court apparently took no account of the doctrine of unconstitutional conditions discussed above.

In Haswell $v$. United States, ${ }^{102}$ the founder of the National Association of Railroad Passengers, a nonprofit organization which engaged in extensive lobbying in support of legislation to expand and improve rail passenger service, sued for a tax refund on the theory that his contributions to the associa-

92. See, e.g., Dumbrowski v. Pfister, 380 U.S. $479,486-87$ (1965).

93. 477 F.2d 1169 (D.C. Cir. 1973), rev'd sub nom. Alexander v. "Americans United" Inc., 416 U.S. 752 (1974).

94. This equal protection argument, though by no means frivolous, is distinguishable from the more general argument stated above that the restriction discriminates among exempt organizations solely on the basis of first amendment activity.

95. 477 F.2d at 1183 .

96. Int. Rev. CoDe of 1954, § 7421 (a).

97. 416 U.S. at 758 .

98. 470 F.2d 849 (10th Cir. 1972), cert. denied, 419 U.S. 864 (1974).

99. The decree of the United States District Court for the Northern District of Oklahoma, entered February 24, 1972, was not officially reported.

100. 470 F.2d at $856-57$.

101. Id. at 857 .

102. 500 F.2d 1133 (Ct. Cl. 1974), cert. denied, 95 S. Ct. 779 (1975). 
tion were deductible as charitable contributions. The taxpayer argued that denial of such a tax deduction constituted an infringement of his first amendment rights of free speech and to petition the legislature. The court of claims rejected this argument primarily on the basis of Cammarano $\%$. United States $^{103}$ in which the Supreme Court had upheld a Regulations' provision denying business expense deductions for lobbying on the ground that it was expressive of a sharply defined policy against government subvention of lobbying. ${ }^{104}$ But, as noted above, the congressional policy against subvention of lobbying by business taxpayers was abandoned in 1962 upon enactment of section 162(e), which had the effect of reversing the Cammarano result. ${ }^{105}$ The court of claims' discussion in Haswell to the effect that it is up to legislature, not the courts, to correct the resulting disparity between business taxpayers and charities ${ }^{106}$ is not responsive to the constitutional issue. The enactment of section 162(e) indicates that there is no sharply defined congressional policy against subvention in general; and in the absence of such a policy, the section $501(c)(3)$ limits on legislative activities are subject to challenge on first amendment grounds.

In any event, the court's holding in Haswell relates only to the issue of whether the restriction on a charity's legislative activity abridges the first amendment rights of a donor. As the court noted, a donor is free to engage in legislative activity on his own or through an organization not described in section 501(c)(3), and the only effect of the restriction is to deny him a tax deduction for such expenses. ${ }^{107}$ The sanction imposed on the charity, which was not a party in the Haswell case, goes far beyond disallowance of a deduction. As Justice Douglas stated in a concurring opinion in Cammarano: ${ }^{108}$

If Congress had gone so far as to deny all deductions for "ordinary and necessary business expenses," if a taxpayer spent money to promote or oppose initiative measures, it would be placing a penalty on the exercise of First Amendment rights.

The restriction on legislative activities places just such a penalty on a charity's exercise of first amendment rights: violation of the restriction results in total denial or withdrawal of the charity's exemption and the right to receive deductible contributions. Thus the holding in Haswell-that the donor's constitutional rights are not violated by the restriction-is not dispositive of the much stronger unconstitutional conditions argument which can be made on behalf of the charity.

\footnotetext{
103. 358 U.S. 498 (1959).

104. 500 F.2d at 1140 .

105. See text accompanying notes 78-85 supra.

106. $500 \mathrm{~F} .2 \mathrm{~d}$ at $1142-43$.

107. 500 F.2d at 1148 .

108. 358 U.S. at 515 .
} 
A fourth action raising constitutional challenges to the restrictions on legislative activity was brought by Tax Analysts and Advocates, a section 501(c)(3) organization, and Taxation With Representation, a section 501(c)(4) organization. ${ }^{109}$ Both organizations sued for (1) a declaratory judgment that the legislative activity restrictions are unconstitutional and (2) an injunction against enforcement of those restrictions to deny an otherwise qualified organization exemption under section 501 (c)(3) and the right to receive tax deductible contributions. Plaintiffs raised the constitutional issues outlined above. ${ }^{10}$ The district court denied a motion to convene a three-judge court to decide the constitutional issues and entered an order dismissing the complaint on the ground that the action is barred by the Declaratory Judgment and Anti-Injunction Acts. ${ }^{111}$ Plaintiffs' appeal from that order was dismissed without opinion by the United States Court of Appeals for the District of Columbia Circuit. ${ }^{112}$

Thus, the merits of the constitutional arguments outlined above have yet to be clearly adjudicated. In "Americans United," the court of appeals acknowledged that plaintiffs had raised a substantial constitutional issue, but no decision was reached on the merits. The Christian Echoes holding of constitutionality involved only the free exercise of religion issue, and the court's sua sponte dicta that the restrictions do not infringe the organization's freedom of speech took no account of the doctrine of unconstitutional conditions. Haswell involved only the constitutional rights of a donor and not those of the charity itself.

Obviously, no one can predict with certainty how the Supreme Court will decide the constitutional issues raised by the legislative activities restriction. It is, however, clear that the restriction inhibits the exercise of fundamental first amendment rights and discriminates among charities on the basis of first amendment activity. It both deters public charities from becoming involved in the legislative process and, because of the breadth and vagueness of the statutory standards, invites further self-censorship on a broad range of issues which may be the subject of legislative action. However the Supreme Court may ultimately decide these issues, they constitute a compelling reason for Congress to enact a clearer, more liberal and less discriminatory statutory

109. Tax Analysts \& Advocates v. Shultz, 376 F. Supp. 889 (D.D.C. 1974).

110. See Brief for Plaintiffs $i d$.

111. 376 F. Supp. at 889 .

112. Tax Analysts \& Advocates v. Simon, 512 F.2d 992 (D.C. Cir. 1975). On appeal, plaintiffs have argued that because Tax Analysts and Advocates is a tax exempt organization, it does not have the option contemplated in the Anti-Injunction Act of paying a tax and suing for a refund. Thus, it has no adequate remedy at law, and equity and due process require that it be allowed to raise its constitutional challenges notwithstanding the Act. Taxation With Representation also appealed the district court's denial of a motion to amend its complaint to claim a refund of the federal unemployment taxes, which claim would have avoided any bar posed by the Act. See generally Center on Corporate Responsibility, Inc. v. Shultz, 368 F. Supp. 863, 879 (D.D.C. 1973). 
standard-one which would better serve the public interest while avoiding infringement of the constitutional rights of public charities and their supporters.

\section{II}

\section{Recent Congressional Action}

In 1968 the American Bar Association recommended that Congress liberalize the legislative activity restriction to allow a public charity to communicate freely with legislators and with its own members and contributors about legislation directly affecting its exempt purpose or function. ${ }^{113}$ In 1971 Senator Muskie introduced a bill in Congress patterned after the ABA proposal. $^{114}$ In January 1972, in response to criticism that the Muskie bill might allow a public charity to devote the bulk of its activities to lobbying, ${ }^{15}$ Senator Muskie and Senator Hugh Scott introduced a modified version of the bill which would require that the charity normally devote substantially more than one-half of its expenditures to exempt activities other than lobbying. ${ }^{116}$

In March 1972, Congressman Ullman and three other members of the House Ways and Means Committee introduced a bill adopting a somewhat different approach. ${ }^{117}$ The Ullman bill would allow a public charity to apply up to 20 per cent of its expenditures to lobbying so long as no more than five per cent of its expenditures were for grassroots lobbying and lobbying on matters not directly related to the organization's exempt purposes. ${ }^{118}$

In May 1972, the Ways and Means Committee held extensive hearings on the Ullman bill, which was strongly endorsed by the Chairman of the President's Council on Environmental Quality, the American Bar Association, the American Civil Liberties Union, and numerous charitable, educational, and religious groups. ${ }^{119}$

The Department of Treasury, while supporting the "objectives" of the Ullman bill, expressed reservations about its structure on three grounds. ${ }^{120}$ First, it objected to the fact that the bill did more than "redress an imbalance" between charities and businesses created by the enactment of section 162(e). ${ }^{121}$ In the Treasury's view, the justification for liberalizing the legisla-

113. American Bar Association, Section on Taxation, Council and Committee Recommendations, 21 TAX LAWYER 921, 967-72 (1968).

114. S. 1408 , 92d Cong., 1st Sess. (1971), in 117 Cong. Rec. 8518 (1971).

115. 118 Conc. Rec. 843 (1972).

116. S. 3063, 92d Cong., 2d Sess. (1972), in 118 Cong. Rec. 844 (1972).

117. Hearings on Legislative Activities by Certain Types of Exempt Organizations, supra note 32, at 2-4.

118. The provision of the Muskie and Ullman bills are discussed and compared in Geske, supra note 81 , at $310-20$.

119. Hearings on Legislative Actizity by Certain Types of Exempt Organizations, supra note 32, at 29.

120. Testimony of Edwin S. Cohen, Assistant Secretary for Tax Policy, id. at 5-27.

121. Id. at 7 . 
tive activities restriction is to allow charities to lobby on matters which are of direct interest both to business taxpayers and to "competing non-business charitable interests." It therefore suggested limiting allowable lobbying by charities to "cases of confrontation" between business and charitable interests. $^{122}$ This limitation, if adopted, would create new ambiguity and further administrative difficulties in identifying cases involving such confrontation. Moreover, reform limited to such cases would cure only the present law's discrimination against charities in comparison to businesses. The other public policy reasons discussed above for allowing charities to participate in the legislative process apply whether or not the charity is faced with a competing business interest.

Second, the Treasury was concerned that the percentage limitations were set too high, noting that 20 per cent of total annual expenditures of all public charities, which could theoretically be devoted to lobbying under the Ullman bill, could amount to as much as six billion dollars. ${ }^{123}$ As other witnesses point out, this concern is greatly exaggerated. ${ }^{124}$ Typically public charities have committed most or all of their annual receipts to their charitable programs and are not in a position to divert substantial funds to lobbying. Many charities are engaged in programs not affected by any pending or proposed legislation and would have little incentive to engage in legislative activities. In light of the continuing risk of loss of tax exempt status, even charities choosing to support or oppose legislation would continue their efforts to stay well within the allowable limits. And it is important that the limits be sufficiently high to allow even a small charity to take an effective role in the legislative process without jeopardizing its exemption.

Treasury's third objection related to a provision in the bill excepting from the definition of legislative activity communication between a public charity and its members. Its spokesman expressed concern that a charity could adopt a "loose" definition of membership encompassing a large segment of the population, thereby using the provision to engage in what amounts to grassroots lobbying. ${ }^{125}$ Despite this concern, the exception for communication with bona fide members is sound, and the potential for abuse could readily be avoided by placing reasonable limits on the statutory definition of members. Section 162(e) expressly allows a deduction for the expenses of communication on legislative matters between a business taxpayer and a trade association or other organization of which the taxpayer is a member. ${ }^{126}$ If a charity is to participate in legislative activity and to act as a spokesman for a public interest on behalf of its members, it must also be in a position to obtain the views of

122. Id.

123. Id. at 8-9.

124. Id. at $58,74,234-36$.

125. Id. at 9 .

126. Int. Rev. Code of 1954, § 162(e)(1)(B); spe Treas. Reg. $\$ 1.162-20(\mathrm{c})(3)(1969)$. 
its members and to communicate with them about its legislative positions and activities.

Following public hearings, the Ullman bill was considered by the House Ways and Means Committee in two executive sessions. However, in part because of Treasury's objections, the Committee failed to take further action.

In March 1973, the sponsors of the Ullman bill introduced a new proposal designed to alleviate some of the concerns expressed by Treasury. ${ }^{127}$ In place of the original ceiling of 20 per cent of total expenditures, the new bill limited lobbying expenditures on the basis of a schedule of percentages which decrease in relation to the size of the organization's overall expenditures. A small organization would be allowed to devote a larger percentage of its expenditures to lobbying than a larger organization, and no organization would be allowed to spend more than $\$ 500,000$ a year on legislative activities. ${ }^{128}$

A somewhat modified form of the bill, introduced in December 1973 by Representative Conable for himself and for the sponsors of the Ullman bill, ${ }^{129}$ was considered at length by the Ways and Means Committee. By this time, the basic statutory amendment first introduced by Senator Muskie had become encumbered with various technical provisions. The inverse graduation provision necessitated a rule which treated affiliated charities as a single entity to avoid abuse through creation of multiple entities. To prevent circumvention of the percentage limits, the new bill provided that no charitable contribution deduction would be allowed to a donor for lobbying expenditures made directly by him on behalf of a charity. The bill also excluded from the definition of legislative activities all communication of information between a charity and its bona fide members related to legislation of direct interest to the charity and its members.

In the course of the committee's consideration of the Conable bill, various controversies arose over the terms and construction of these provisions and over additional technical issues. Concern was expressed that a charity which lost its section $501(\mathrm{c})(3)$ exemption as a result of legislative activity might secure an exemption under section $501(\mathrm{c})(4)$ and continue to lobby with funds previously received through deductible contributions; various termination provisions were suggested to prevent this result. ${ }^{130}$ Questions were raised

127. H.R. 5095, 93d Cong., lst Sess. (1973).

128. The schedule would allow lobbying expenditures of 15 per cent of the first $\$ 200,000$ of total expenditures; 10 per cent of the next $\$ 200,000$; 5 per cent of the next $\$ 200,000$; and 1 per cent of the remainder up to a total of $\$ 500,000$ in lobbying expenditures.

129. H.R. 14443, 93d Cong., 2d Sess. (1974).

130. H.R. 5095, supra note 127, contained a provision levying a substantial termination tax (equal to the lesser of (a) 30 per cent of the value of the charities assets and (b) the aggregate tax benefit attributable to its exempt status) on an organization which lost its section $50 \mathrm{l}(\mathrm{c})(3)$ exemption. The sponsors of the Conable bill recommended instead a provision denying a section $501(c)(4)$ exemption to a charity which lost its section $501(\mathrm{c})(3)$ exemption by virtue of its legislative activities. 
about the appropriate definition of affiliated organizations and the character of communications that should be allowed between a charity and its members. Objections were raised to proposed language in the bill providing that legislative activity expenditures could not "normally" exceed the amounts allowed; and it was suggested that the percentage limitations should apply each year with no allowance for averaging over several years. ${ }^{131}$

On August 2, 1974 the Ways and Means Committee gave preliminary approval to the Conable bill as a part of the proposed Tax Reform Act, subject to certain minor modifications of the affiliated organizations and termination provisions. But on the eve of final approval of the Tax Reform Act, the bill was substantially rewritten by the staffs of the Treasury, Joint Committee, and House Legislative Counsel. Because it was then too late to effect further substantive changes in the draft, the Conable bill was dropped from the Act on motion of its sponsors. ${ }^{132}$

On June 18, 1975, the sponsors of the Conable bill introduced a new bill in the ninety-fourth Congress which is similar to the Conable bill as tentatively approved by the Ways and Means Committee in 1974 but provides higher percentage limitations on allowed lobbying expenditures. ${ }^{133}$ On December 19, 1975, Senators Muskie, Scott, Dole, Nelson, and thirty-nine other sponsors introduced an identical bill in the Senate. ${ }^{134}$ On May 3, 1976, a modified version of the Conable bill was introduced in the House. ${ }^{135}$ The Ways and Means Committee held hearings on the modified Conable bill on May 12, 1976, and reported the bill to the House without substantial changes on June 2, 1976.

\section{Conclusion}

The Code's restrictions on legislative activities by public charities, as interpreted by the Treasury and applied by the Revenue Service, raise serious

131. "Normally" would presumably be interpreted as requiring compliance for three of the prior four years or for the average of the prior four years. See INT. REv. Code OF 1954, $\$ 4942$ (f)(2); Treas. Reg. \$53.4942(b)-3(a) (1972).

132. See Staff of the Joint Comm. on Internal Revenue Taxation, 93d Cong., 2d Sess., Tax Reform Bill of 1974, Tentative Decisions of the Ways and Means Comm. Since Sept. 11, 1974, Corresponding to Sections of the Draft Bill 12 (Comm. Print 1974).

133. H.R. 8021, 94th Cong., lst Sess. (1975). The new bill would allow lobbying expenditures of 20 per cent of the first $\$ 500,000$ of the organization's total expenditures; 15 per cent of the next $\$ 500,000 ; 10$ per cent of the next $\$ 500,000$; and 5 per cent of the remainder up to a total of $\$ 1,000,000$ in lobbying expenditures.

134. S. 2832, 94th Cong., 1st Sess. (1975).

135. H.R. 13500, 94th Cong., 2d Sess. (1976). This bill is substantially similar to H.R. 8021 , supra note 133 and S. 2832, supra note 134 . The principal modifications adopted in the new bill are: (a) expenditures for "grassroots" lobbying are limited to 25 per cent of the organization's total allowable lobbying expenditures; (b) an organization will not lose its exemption unless its lobbying expenditures "normally" exceed 150 per cent of the allowed amounts, but it must pay an excise tax of 25 per cent of any expenditures in excess of the allowed amounts; and (c) an organization (other than a religious organization) which loses its exemption by virtue of legislative activities will not be eligible for exemption under section 501 (c)(4). 
practical difficulties. In the absence of more precise definitions and guidelines, fair and nondiscriminatory administration of the restrictions is unduly difficult, and charities are assured of compliance only if they forgo most activities that could be construed as support of, or opposition to, legislation. Moreover, both the concept and the effect of the restriction are contrary to sound public policy. Charities have a legitimate interest in legislative issues and are capable of making a significant contribution to the formulation of legislation. Yet they are effectively excluded from the legislative process on penalty of loss of exempt status. As Professor Elias Clark has pointed out: "They find themselves in the anomalous position of speaking with a hesitant, muted voice when every practical consideration requires that their approach be forceful and clear."136

In response to mounting criticism of the restrictions, legislation has been introduced repeatedly which would allow public charities to speak with a forceful and clear voice on behalf of public and charitable interests. But despite five years of congressional activity and broad bipartisan support, the legislation has become bogged down repeatedly in technicalities which have little to do with the substantive issues involved. The Ullman bill, which would have placed reasonable and definite percentage limits on expenditures for legislative activities, represented a sound approach to reform. Treasury's concern that it would have invited abuse appears greatly exaggerated since charities' lobbying expenditures would continue to be limited by fiscal constraints as well as by section $501(\mathrm{c})(3)$ requirements that their activities relate solely to charitable purposes and not be conducted for the benefit of private individuals.

Realistically, however, enactment of a bill based on the Ullman proposal is doubtful in light of the Treasury's opposition. The Conable alternative based on an inversely graduated scale of allowed percentages, although unnecessarily restrictive, represents a reasonable compromise between the need for definite and more liberal standards for participation by charities in the legislative process and the Treasury's concern over abuses. The modified version of the Conable bill introduced in this session of Congress has the support of the Treasury. ${ }^{137}$ Hopefully it will be enacted; reform is long overdue.

136. Clark, supra note 8 , at 454 .

137. See Hearings on H.R. 13500 Before the House Comm. on Ways and Means, 94th Cong., 2d Sess. (1976) (testimony of William M. Goldstein, Deputy Assistant Treasury Secretary for Tax Policy). 